\title{
A Mesoproterozoic continental flood rhyolite province, the Gawler Ranges, Australia: the end member example of the Large Igneous Province clan
}

\author{
M. J. Pankhurst ${ }^{1,2}$, B. F. Schaefer ${ }^{1,2}$, P. G. Betts ${ }^{2}$, N. Phillips ${ }^{2}$, and M. Hand ${ }^{3}$ \\ ${ }^{1}$ GEMOC, Earth and Planetary Sciences, Macquarie University, North Ryde, NSW, 2109, Australia \\ ${ }^{2}$ School of Geosciences, Monash University, Melbourne, 3800, Australia \\ ${ }^{3}$ School of Geology and Geophysics, Adelaide University, Adelaide, SA, 5001, Australia
}

Received: 15 August 2010 - Published in Solid Earth Discuss.: 9 September 2010

Revised: 22 February 2011 - Accepted: 22 February 2011 - Published: 31 March 2011

\begin{abstract}
Rhyolite and dacite lavas of the Mesoproterozoic upper Gawler Range Volcanics (GRV) $\left(>30000 \mathrm{~km}^{3}\right.$ preserved), South Australia, represent the remnants of one of the most voluminous felsic magmatic events preserved on Earth. Geophysical interpretation suggests eruption from a central cluster of feeder vents which supplied large-scale lobate flows $>100 \mathrm{~km}$ in length. Pigeonite inversion thermometers indicate eruption temperatures of $950-1100^{\circ} \mathrm{C}$. The lavas are A-type in composition (e.g. high $\mathrm{Ga} / \mathrm{Al}$ ratios) and characterised by elevated primary halogen concentrations ( $\sim 1600 \mathrm{ppm}$ fluorine, $\sim 400 \mathrm{ppm}$ chlorine). These depolymerised the magma such that temperature-compositionvolatile non-Arrhenian melt viscosity modelling suggests they had viscosities of $<3.5 \log \eta$ (Pas). These physicochemical properties have led to the emplacement of a Large Rhyolite Province, which has affinities in emplacement style to Large Basaltic Provinces. The low viscosity of these felsic magmas has produced a unique igneous system on a scale which is either not present or poorly preserved elsewhere on the planet. The Gawler Range Volcanic Province represents the erupted portion of the felsic end member of the family of voluminous, rapidly emplaced terrestrial magmatic provinces.
\end{abstract}

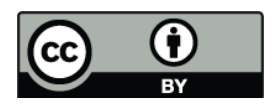

Correspondence to: M. J. Pankhurst (matthew.pankhurst@mq.edu.au)

\section{Introduction}

The viscosity of silicate magmas is a critical control on the rate and scale of planetary differentiation, material and heat transfer, and crustal growth (Reese et al., 1998; Zaranek and Parmentier, 2004). Large Igneous Provinces (LIPs) represent relatively short periods of time during which significant volumes of material are emplaced in or onto the crust $(<50 \mathrm{Myr}$, $>0.1 \mathrm{Mkm}^{3}$ respectively, according to the classification of Bryan and Ernst, 2008). Most LIPs manifest as dominantly low-viscosity mafic magma outpourings (e.g. Coffin and Eldholm, 1994), during which large volumes of mantle-derived lava are expelled onto the Earth's surface in short geologic timescales (5-10 Myr; Jerram and Widdowson, 2005). These principally basaltic occurrences are often described as the result of mantle plume activity, and although a variety of models exist, and debate continues (Bryan and Ernst, 2008 and references therein). In contrast, Silicic Large Igneous Provinces are rare, dominated by explosive eruptions, generally accumulate as pulses over longer timescales, and occur as a result of plate margin processes (Bryan, 2007; Bryan et al., 2002). In addition to the magmatic products of SLIPs, Pankhurst et al. (2011) recognise examples of rapid voluminous felsic magmatism within otherwise mafic-dominated LIPs.

This contribution investigates a Continental Flood Rhyolite Province, and argues that its characteristics are a function of the inherent low viscosity of the magmas involved. We suggest that a typical plate margin setting does not adequately explain the geometry, duration, temperatures, chemistry and magmatic processes of the GRV, placing it outside

Published by Copernicus Publications on behalf of the European Geosciences Union. 
the conceptual model for "normal" Silicic Large Igneous Provinces.

The viscosity of natural silicate melts ranges over more than 10 orders of magnitude (Cashman et al., 1998; Romano et al., 2001) and represents a complex interplay between temperature and compositional factors. These include silica content, crystallite content, alkali/Al ratio, water content, halogen concentration and oxygen fugacity (Dingwell et al., 1985, 1988, 1993; Dingwell and Virgo, 1988; Giordano et al., 2004b; Mysen and Virgo, 1989; Mysen, 1990; Webster and De Vivo, 2002; Webster and Rebbert, 1998). The viscosity of felsic magmas is generally many orders of magnitude greater than that of mafic magmas because the former are inherently more polymerised and usually more crystal rich (e.g. Giordano et al., 2006). Further, felsic magmas generally erupt at significantly lower temperatures than do mafic magmas, and thus substantial lava flows analogous to those of flood basalt provinces are rare in the geologic record (Christiansen et al., 1984; Haapala et al., 2007; Milner et al., 1992). A-type felsic magmas though, tend to be lower viscosity than magmas of comparable silica concentration. Clemens et al. (1986) postulated that this could be due to higher temperatures and elevated halogen content most often associated with A-types. Recent advances in physicochemical models (e.g. Giordano et al., 2008) which incorporate a large number of variables for felsic compositions now allows quantitative calculation of magma intensive parameters, and thus more rigorous testing of geological and geophysical observations.

In this contribution we apply a combination of aeromagnetic and physicochemical analysis to the Mesoproterozoic (1592 \pm 2 Ma; Fanning et al., 1988) upper Gawler Range Volcanics, South Australia. We demonstrate that a large felsic magmatic system can behave like a mafic large igneous province given an appropriate combination of viscositylowering factors, notably eruption temperature and halogen content.

\section{Age and morphology of the upper Gawler Range Volcanics}

The upper Gawler Range Volcanics are one component of an extensive, dominantly A-type (Blissett et al., 1993) felsic large igneous province (Allen et al., 2008) comprising the ca. 1595-1592 Ma Gawler Range Volcanics and coeval Hiltaba Granite Suite (ca. 1600-1575 Ma; Fanning et al., 1988). The upper Gawler Range Volcanics are composed of three thick $(>250 \mathrm{~m})$, chemically and isotopically laterally homogeneous dacite to rhyolite $\left(67-74 \mathrm{wt} \% \mathrm{SiO}_{2}\right)$ lavas with preserved outcrop extent of over $12000 \mathrm{~km}^{2}$ across the central Gawler Craton (Allen and McPhie, 2002; Allen et al., 2003, 2008; Fig. 1). The Eucarro Rhyolite and Pondanna Dacite member of the Yardea Dacite are investigated within this study. The duration of upper Gawler Range Volcanics

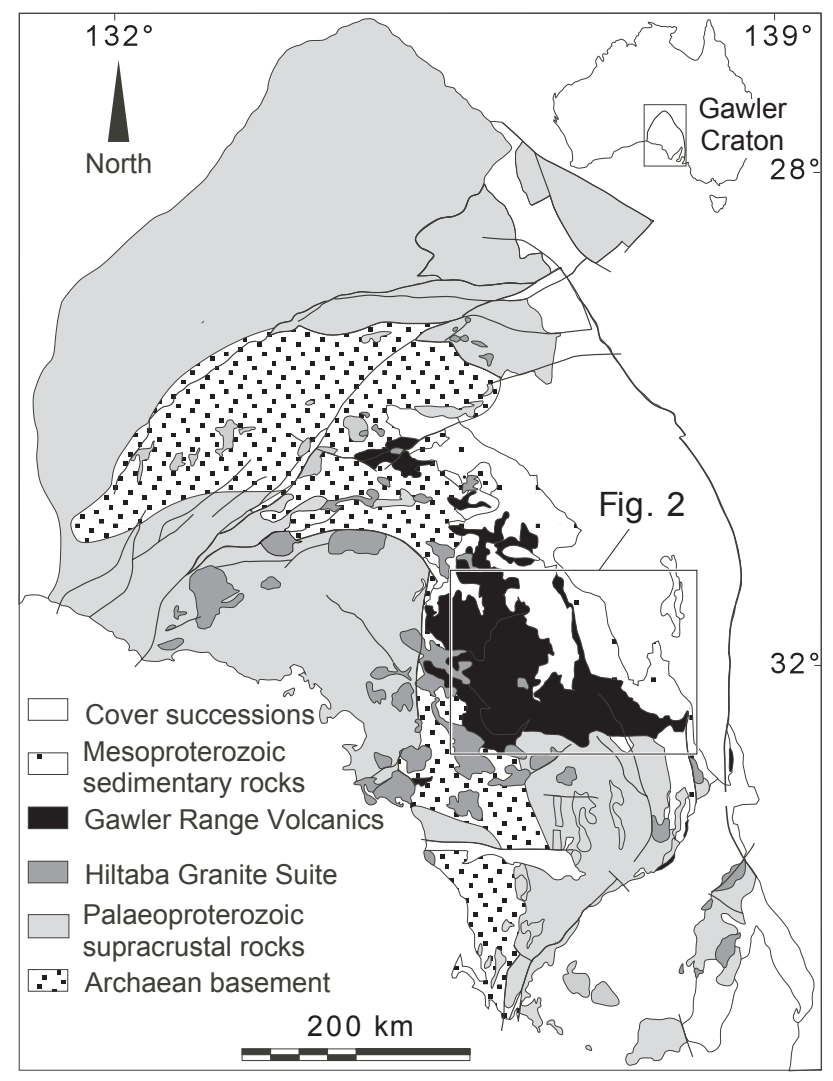

Fig. 1. Simplified geological map of the Gawler Craton.

magmatism is currently constrained to be $<2 \mathrm{Ma}$ (Fanning et al., 1988). Significantly, basalts and basaltic-andesites comprise a volumetrically miniscule proportion of the complete terrain («10\%; Allen et al., 2008), and are absent (except for some mafic enclaves) in the lithologies investigated here.

These volcanic rocks, which are a constituent of the last tectonothermal event to occur within the central Gawler Craton, are imaged in regional high-resolution aeromagnetic data as a series of overlapping radiating lobes characterised by a heterogeneous (wavelength $1-5 \mathrm{~km}$ ) moderatehigh magnetic signal (Fig. 2). Lobe fronts are arcuate features defined by a combination of changes in magnetic intensity and texture. Recent anisotropy of magnetic susceptibility (AMS) data obtained in independent studies from the interpreted lobe fronts in the southern Gawler Ranges (McPhie et al., 2008) preserve steeply dipping and bimodal orientations. We consider these orientations to be consistent with flow patterns at the termination of individual lobes, and a magma source to the northeast, contrasting with McPhie et al. (2008) interpretation of a southwest source. In exposed southern areas, these lobes correspond with mappable single lobes within the upper Gawler Range Volcanics (e.g. Allen et al., 2003), whereas in the northeast of the provice aeromagnetic data suggest that the lobes clearly persist beneath younger sedimentary cover (Fig. 2). The total preserved distribution 


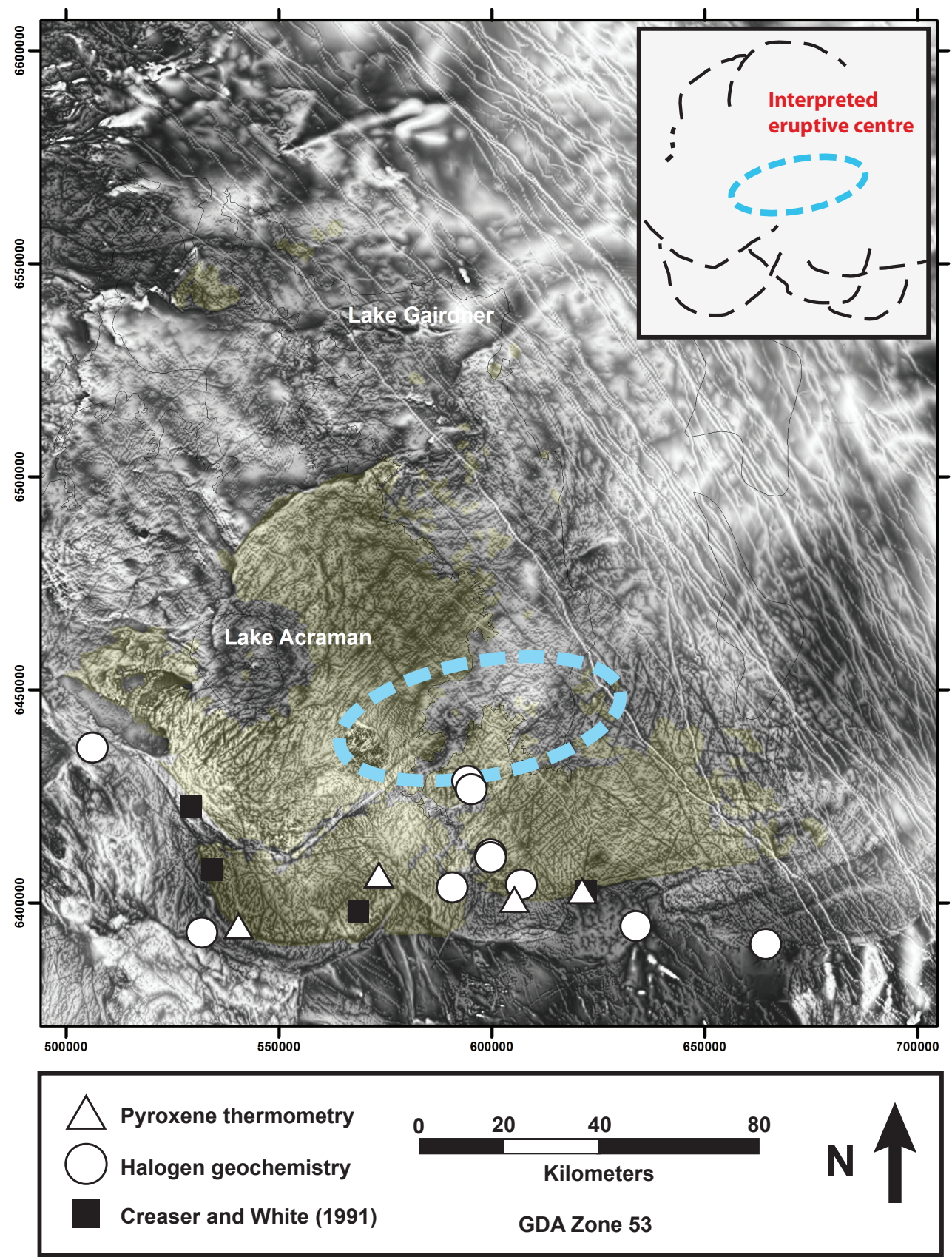

Fig. 2. Sample sites superimposed onto reduced-to-the-pole greyscale aeromagnetic image of the Gawler Range Volcanics. The lobe morphology of the lava flows can be observed as regions of similar magnetic texture defined by arcuate shapes. The (preserved) flow fronts closely follow the modern outcrop distribution (inset) in the SW and these shapes are also imaged undercover (NE of Lake Gairdner).

of the upper Gawler Range Volcanics suggests an ellipticalshaped lobate architecture in which the median lines of each lobe emanate from a central cluster, which is characterised by a longer wavelength, elliptical medium wavelength $(\sim 5-$ $10 \mathrm{~km})$ magnetic signal interpreted as sub-volcanic features, including pipes/feeder complexes and frozen magma chambers (Fig. 2). Previous geophysical work interpreted the apparent lobate geometry of the lavas to be caused by the intersection of the Earth's surface and gentle tilting of the province (Rajagopalan et al., 1993). If the geometry was due to erosion only, all the lobes would have the same geometry - i.e. they would curve in the same direction no matter where they exist in the belt. This is not the case; above and below sedimentary cover the lobes are radial, implying a central source, and thus appears to reflect the primary lava distribution (Fig. 2). 


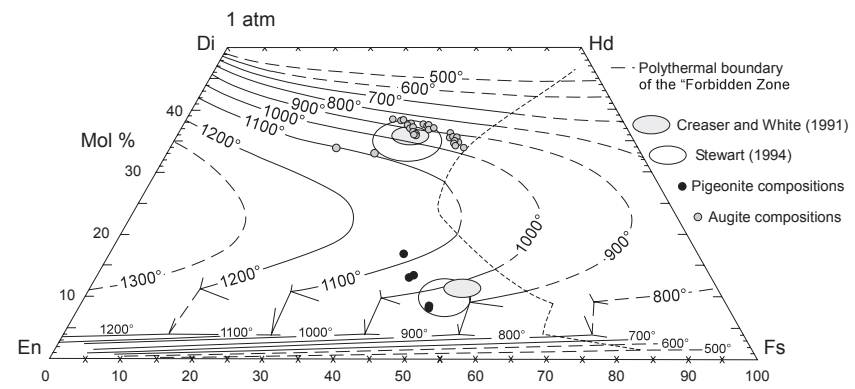

Fig. 3. Graphical pyroxene geothermometer after Lindsley (1983). Pigeonite and augite data from Creaser and White (1991), Stewart (1994) and this study indicate magmatic temperatures between $900^{\circ} \mathrm{C}$ and $1110^{\circ} \mathrm{C}$ for the upper Gawler Range Volcanics.

\section{Viscosity calculations}

Recent advances in quantitative modelling of silicate melt viscosity, based largely around improvements in experimental constraints (Giordano and Dingwell, 2003; Giordano et al., 2004a, b, 2006, 2008) allow rigorous calculation of viscosity, particularly for magmas with low crystallite content. These models incorporate the effects of depolymerising agents, such as halogens, for bulk compositions and temperatures appropriate for the GRV. We utilise a conservative approach where whole rock fluorine contents are used to provide a minimum estimate for the de-polymerising agents, resulting in maximum values for calculated viscosities at the lowest measured reasonable temperature estimates.

Pyroxene and feldspar geothermometry studies of the Yardea Dacite indicate that the upper Gawler Range Volcanics record temperatures between $950-1100{ }^{\circ} \mathrm{C}$ (Creaser and White, 1991; Stewart, 1994). New temperature data from a range of new localities within the province (Figs. 2 and 3 ) based on pigeonite inversion geothermometry (Lindsley, 1983) support these observations (Fig. 3). Hence we consider the best estimate for the eruptive temperature of the upper Gawler Range Volcanics to be between $\sim 950-1050^{\circ} \mathrm{C}$. Due to the remarkable chemical homogeneity of the single lavas over hundreds of kilometres (Creaser and White, 1991; Giles, 1988; Stewart, 1994), we can make the reasonable assumption that the magma system feeding the volcanism was thoroughly mixed via convection, and therefore maintained a relatively constant temperature throughout. Since the geothermometry data range over $\sim 200^{\circ} \mathrm{C}$, and the geothermometer (Lindsley, 1983) generally records cooling, we suggest that surface cooling was mostly responsible for the observed spread (Fig. 3) and therefore it is possible that eruptive temperature exceeded $1100^{\circ} \mathrm{C}$. Samples from this study were invariably obtained from the terminal portions of the lava lobes (Fig. 2), which are more likely to record cooling during emplacement.

Samples of Gawler Range Volcanics (Fig. 2) were observed visually in the field, hand sample and microscopi- cally to possess a high degree of homogeneity (phenocrysts of K-feldspar > quartz $>$ pyroxene $>$ Fe-oxides totaling $<20-25 \%$ within a microcrystalline matrix). The observation of such homogeneity over their wide geographical extent is significant when considering the degree of alteration (or lack thereof) for the GRV samples. Alteration would be predicted to have acted non-systematically in both a petrographic and geochemical sense, and this is not observed within the units investigated in this study. Following petrological work to confirm the primary nature of their textures and low abundance of microphenocrysts within the microcrystalline matrix, the cores of twelve $\sim 5 \mathrm{~kg}$ samples of unaltered upper Gawler Range Volcanics were analysed for major, minor (including halogens) and trace elements using a Bruker-AXS S4 Pioneer XRF Spectrometer and processed through Bruker-AXS Spectra-plus Software at the Advanced Analytical Centre at James Cook University. The standard used for $\mathrm{F}$ and $\mathrm{Cl}$ was FSL, lower detection limits for both $\mathrm{F}$ and $\mathrm{Cl}$ were $0.02 \%$. Pellets were kept in a desiccator from the time of pressing to the analytical run to minimize the risk of $\mathrm{Cl}$ contamination. Mineral assemblages (feldspar, ferromagnesian phases and rare quartz) and their abundances, and major (see Table 2) and trace element results duplicate that of previous studies (Allen and McPhie, 2002; Allen et al., 2003; Fanning et al., 1988; Giles, 1988). Fluorine and chlorine concentrations averaged $\sim 1600 \mathrm{ppm}$ and $\sim 400 \mathrm{ppm}$ respectively (Table 1). These values are significantly higher than those of typical felsic intrusions (300-515 and 50-180 ppm respectively (Gao et al., 1998), which have not experienced volcanic degassing and hence should be expected to have higher halogen contents than their extrusive equivalents. The upper Gawler Range Volcanics exhibit A-type chemical affinities (Fanning et al., 1988; Giles, 1988), and due to their absence of common granitic hydrous phases (e.g. biotite), consistent with the low values of loss on ignition (LOI) typically between 1-2 wt \%, magmatic water content during emplacement can be considered low (1-2 wt \%).

Crystallite content has an important positive influence on magma viscosity (e.g. Pinkerton and Stevenson, 1992), particularly at concentrations $>45 \%$ (Bagdassarov et al., 1994). Experimental work by Lejeune and Richet (1995) suggests that magmas with crystallite concentrations $<40 \%$ exhibit Newtonian behaviour. Since the upper GRV observable crystallite content is low (excluding phenocryst abundance), phenocryst abundance does not exceed 40\% (average 20-25\%, max 39\%; Allen et al., 2003), this influence is minimal, and is considered less important relative to thermal and chemical controls.

Temperature and major element data have been input to the Giordano et al. (2008) magmatic liquid viscosity model, chosen since it is calibrated for fluorine. Currently, there is debate concerning the specific role chlorine plays in depolymerising the melt structure (Zimova and Webb, 2006, 2007), and for this reason we withheld chlorine data from our calculations. Results of the combined modelling encapsulating 
Table 1. Measured (XRF) halogen concentrations for the Eucarro Rhyolite and Yardea Dacite. Note values are likely to be minimum measurements due to devolatilisation and degassing during eruption.

\begin{tabular}{lcc}
\hline & F ppm & Cl ppm \\
Detection Limit & 200 & 200 \\
\hline Eucarro Rhyolite & & \\
GRER01 & 1400 & 380 \\
GRER03 & 290 & 680 \\
GRER07 & 1960 & 310 \\
GRER09 & 1920 & 360 \\
Pondanna Dacite & & \\
GRYD18 & 1470 & 330 \\
GRYD19 & 1670 & 430 \\
GRYD20 & 1340 & 390 \\
GRYD23 & 1390 & 290 \\
GRYD24 & 1290 & 310 \\
GRYD25 & 1840 & 360 \\
GRYD28 & 1790 & 460 \\
GRYD29 & 1770 & 490 \\
\hline
\end{tabular}

non-Arrhenian behaviour are summarised in Table 2. The most significant outcomes are that for bulk compositions appropriate to the upper GRV, viscosities are typical for dry compositions at typical rhyolitic eruption temperatures $\left(\sim 800^{\circ} \mathrm{C}\right)$. Calculated viscosities drop by several orders of magnitude (Table 2) at $950-1100^{\circ} \mathrm{C}$ for both the Eucarro Rhyolite and Pondanna Dacite (Fig. 4), and there is a further viscosity decrease when volatile contents appropriate for the Gawler Range Volcanics $\left(\sim 1.5 \mathrm{wt} \% \mathrm{H}_{2} \mathrm{O}\right.$ and $\sim 0.2 \mathrm{wt} \%$ fluorine) are included in the models; resulting in viscosities of $\sim 3.25$ and $\sim 4.25 \log \eta(\mathrm{Pas}$ ) for the Pondanna Dacite and Eucarro Rhyolite respectively. Given that the volatile (particularly halogen) estimates are conservative $(\mathrm{Cl}$ is not included), and that evidence for eruptive temperatures as high as $1100^{\circ} \mathrm{C}$ exists, it is conceivable that viscosity could be as low as $\sim 2.5-3 \log \eta$ (Pa s) for the upper Gawler Range Volcanics (Table 2, Fig. 4).

\section{Discussion}

A consequence of the Giordano et al. (2008) model is that an increase in eruptive temperature of $100^{\circ} \mathrm{C}$ or $1 \mathrm{wt} \%$ volatiles in solution equates to a viscosity decrease of around one order of magnitude. Hence the calculated viscosities are sensitive to the input parameters, and we now explore the consequences of this. Firstly, we may consider the actual abundance, and therefore influence, of volatiles to be greater than that recorded. Final degassing of the lava pile producing amygdaloidal flow tops (Allen et al., 2003) could lead to undervaluing of the halogen influence. Conversely, we may be over-estimating the water content of these liquids by as-
Table 2. Calculated viscosities (log $\eta(\mathrm{Pa} s))$ for the Upper Gawler Range Volcanics with reference to a typical (theoretical) tholeiite composition using the equations of Giordano et al. (2008). Note the $\sim 7$ orders of magnitude difference between rhyolitic and basaltic viscosities at their respective typical eruptive temperatures, compared with the $\sim 1$ order of magnitude between calculated Gawler Range Volcanics at $1100{ }^{\circ} \mathrm{C}$ with $\sim 2.2 \mathrm{wt} \%$ total volatiles and a typical tholeiitic basalt composition at typical eruptive temperature.

\begin{tabular}{|c|c|c|c|c|}
\hline (all in wt $\%$ ) & $\begin{array}{l}\text { Eucarro } \\
\text { Rhyolite* }\end{array}$ & $\begin{array}{l}\text { Pondanna } \\
\text { Dacite* }\end{array}$ & $\begin{array}{l}\text { Tholeiitic } \\
\text { Basalt** }\end{array}$ & \\
\hline $\mathrm{SiO}_{2}$ & 70.9 & 67.6 & 50.0 & \\
\hline $\mathrm{TiO}_{2}$ & 0.5 & 0.7 & 1.5 & \\
\hline $\mathrm{Al}_{2} \mathrm{O}_{3}$ & 13.3 & 13.8 & 15.0 & \\
\hline $\mathrm{FeO}(T)$ & 2.8 & 4.3 & 11.0 & \\
\hline $\mathrm{MnO}$ & 0.1 & 0.1 & 0.2 & \\
\hline $\mathrm{MgO}$ & 0.1 & 1.1 & 8.0 & \\
\hline $\mathrm{CaO}$ & 0.9 & 1.1 & 11.5 & \\
\hline $\mathrm{Na}_{2} \mathrm{O}$ & 3.2 & 3.4 & 2.0 & \\
\hline$K_{2} \mathrm{O}$ & 5.7 & 5.2 & 0.2 & \\
\hline$P_{2} \mathrm{O}_{5}$ & 0.1 & 0.2 & 0.1 & \\
\hline$F$ & 0.20 & 0.23 & 0.00 & \\
\hline \multicolumn{4}{|c|}{$\begin{array}{l}\text { Viscosity } \\
\text { (all in } \log \eta \text { Pas) }\end{array}$} & $\begin{array}{c}\text { Temperature } \\
\left({ }^{\circ} \mathrm{C}\right)\end{array}$ \\
\hline \multirow{4}{*}{ Dry*** } & 10.3 & 9.7 & 5.4 & 800 \\
\hline & 7.8 & 7.2 & 3.2 & 950 \\
\hline & 6.0 & 5.5 & 1.8 & 1100 \\
\hline & 7.5 & 7.0 & & 800 \\
\hline \multirow{3}{*}{$1 \mathrm{wt} \% \mathrm{H}_{2} \mathrm{O}$} & 5.8 & 5.3 & & 950 \\
\hline & 4.5 & 4.0 & & 1100 \\
\hline & 6.5 & 6.0 & & 800 \\
\hline \multirow{2}{*}{$2 \mathrm{wt} \% \mathrm{H}_{2} \mathrm{O}$} & 5.0 & 4.6 & & 950 \\
\hline & 3.8 & 3.4 & & 1100 \\
\hline
\end{tabular}

\footnotetext{
* Data are averages; Eucarro Rhyolite $n=4$; Pondanna Dacite $n=8$ ** Typical, theoretical composition

*** "Virtually dry" input used $=0.02 \mathrm{wt} \% \mathrm{H}_{2} \mathrm{O}$ in accordance with Giordano et
} al. (2006) tholeiitic basalt input used $=0.50 \mathrm{wt} \% \mathrm{H}_{2} \mathrm{O}$

suming that LOI corresponds broadly to $\mathrm{H}_{2} \mathrm{O}$. Creaser and White (1991) estimated water content in the Yardea Dacite by comparing the assemblages of quartz, plagioclase, and alkali feldspar phenocrysts at a temperature of $900-1000^{\circ} \mathrm{C}$ and an assumed pressure of $2 \mathrm{MPa}$ with experimentally derived data (Nekvasil, 1988). This estimate yielded a maximum water content of $1 \mathrm{wt} \%$, consistent with the typical estimate obtained from LOI.

This water content would increase further to $2 \mathrm{wt} \%$ if the pressure was increased to $8 \mathrm{MPa}$ (Creaser and White, 1991). Hence our conservative estimate of $\sim 1 \% \mathrm{H}_{2} \mathrm{O}$ may be considered to be a reasonable minimum.

Estimates of halogen contents are also likely to be minima. Fluorine is abundant in all units sampled, implying it was elevated throughout the magma. This is consistent with studies that suggest that $\mathrm{F}$ is soluble in silicate melts at eruptive conditions and hence the majority of loss through volatilisation would not have occurred before eruption (Aiuppa et al., 


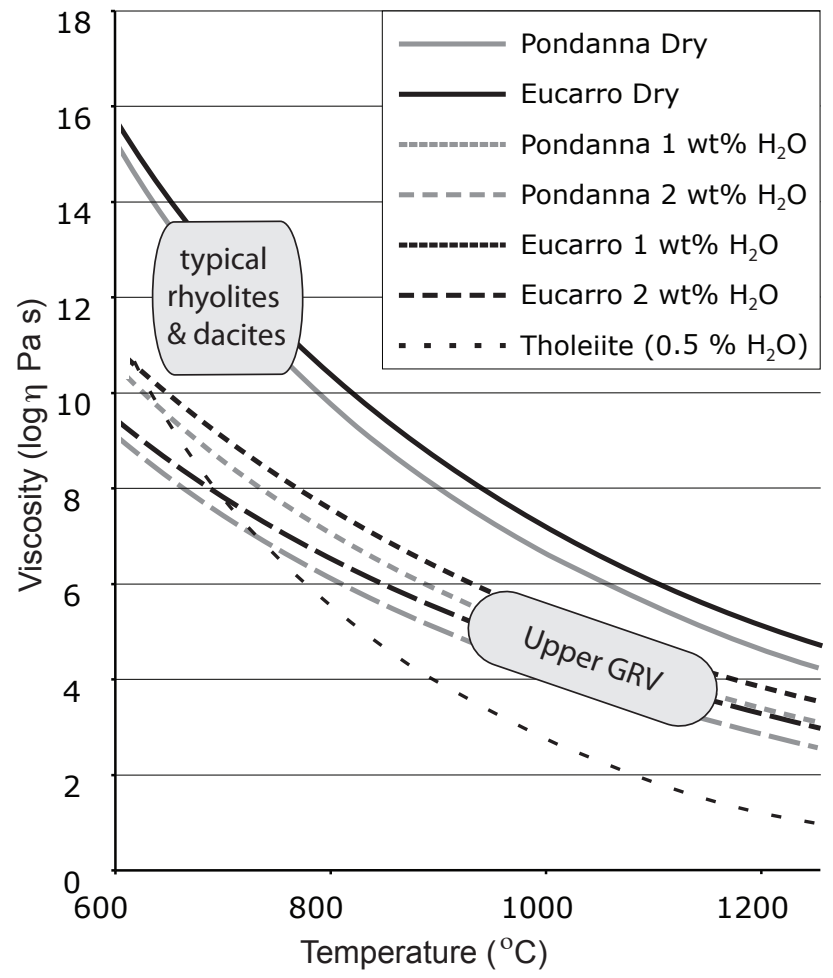

Fig. 4. Viscosity vs. Temperature plot illustrating calculated palaeoviscosities of Pondanna Dacite and the Eucarro Rhyolite using measured fluorine and $0.02,1$ and $2 \mathrm{wt} \% \mathrm{H}_{2} \mathrm{O}$ contents for these units. A typical theoretical tholeiitic basalt composition (see Table 2) has also been modeled for comparison. The results indicate that a combination of unusually high magmatic temperatures and elevated halogen content decrease the viscosity of melts of the composition of the Gawler Range Volcanics towards typical values of basalts.

2002; Holtz et al., 1993). This contrasts with the behaviour of $\mathrm{Cl}$ and water, both of which are highly volatile and would be expected to be variably degassed within and between units during eruption (Aiuppa et al., 2002). Therefore, our estimates for the total volatile content must be regarded as conservative minima, and any increase in concentration of these species will be accompanied by a concomitant decrease in total viscosity.

The second major source of uncertainty in the calculated viscosities is derived from the estimates of eruptive temperature. The calculations are therefore informed by the lowest reasonable eruptive temperature estimates in order to constrain the maximum probable eruptive viscosities. Temperature calculations are based on samples collected from within the frontal part of individual lobes or at the lobe front where temperatures are likely to record maximum cooling. Hence this parameter is one of the least significant in terms of uncertainty in the viscosities obtained.

The physico-chemical modelling suggests that a combination of elevated temperatures during eruption coupled with high fluorine and moderate $\mathrm{H}_{2} \mathrm{O}$ contents reduced the eruptive viscosities of the upper Gawler Range Volcanics to values approaching those of tholeiitic basalts at eruption temperatures of $950^{\circ} \mathrm{C}$ (Fig. 4). The role of fluorine is double in such a system because it increases water solubility as well as acting as a depolymerising agent itself (e.g. Dingwell et al., 1985). Such low viscosities in felsic compositions are exceedingly rare in the geologic record (e.g. topaz rhyolites; Taylor and Fallick, 1997), particularly in volcanic piles that have experienced degassing and halogen loss. More significantly, the Gawler Range Volcanics are anomalous in that they maintained these conditions throughout such a large volume, and were erupted over such a short time $(<2 \mathrm{Myr})$ in comparison with other felsic LIPs ( $\leq 40 \mathrm{Myr}$; Bryan et al., 2002).

The morphology of the volcanic province is characterised by an overlapping lobate flow pattern that radiates from a central zone (Fig. 2). The length scale of single lobes varies between 60 and $120 \mathrm{~km}$, with single lobe fronts and associated terminal lobes between 30 and $120 \mathrm{~km}$ across. The protracted denudation history of the Gawler felsic large igneous province is of great importance to note. Since emplacement at $\sim 1600 \mathrm{Ma}$ the province has been extensively eroded, and now we observe the remains of (if the distribution of similar-aged granitic plutons is a useful proxy, see Fig. 1) what would have probably been a far larger volcanic expression of the system. The dimensions of such a system are characteristic of "classic" mafic large igneous provinces (Bondre et al., 2004; Coffin and Eldholm, 1994; Courtillot et al., 2003; Jerram and Widdowson, 2005; White and Mckenzie, 1995), in which the high magma flux rates and low viscosities enable long lava flow lengths. The radiating morphology of the lobes emanating from a central zone is consistent with that observed in modern shield volcanoes (Thouret, 1999). Hence emplacement and eruption of the high temperature, voluminous upper Gawler Range Volcanics may be considered to be physically analogous to the plume head processes associated with Continental Flood Basalts. Indeed, they are preserved on a comparable scale to the more familiar analogues and have been argued to represent plume derived magmatism from independent chemical and temporal studies. Betts et al. (2007) use palaeomagnetic data and age progression of A-type magmatism across the Gawler Craton, Curnamona province and Mount Isa Inlier to define an equivalent small circle that relates to Australia's polar wander up to the emplacement event. This suggests hotspot progression, and therefore plume activity, independent of geochemical constraints. Betts et al. (2009) incorporate these observations into a regional geodynamic model that appeals to plume-modified orogenesis in eastern Precambrian Australia.

Perhaps then, the tectonic setting of the GRV has hallmarks of the voluminous, (often A-type) felsic magmatism associated with the evolution of the Yellowstone hotspot (e.g. Hildreth et al., 1991) and the Parana-Etendeka plume (e.g. Ewart et al., 1998). 


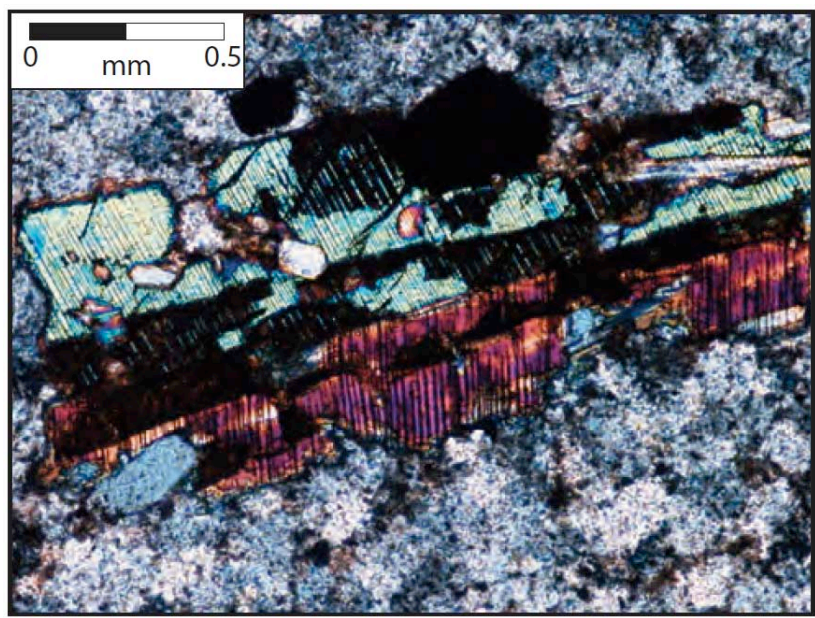

Fig. 5. Photomicrograph (sample YD23, crossed-polarized light) of a pigeonite crystal within unaltered microcrystalline matrix displaying classic "Christmas tree texture"; a result of exsolution lamellae indicating high temperatures (especially for dacite-rhyolite compositions).

We therefore envisage a spectrum of volcanic flood provinces which range from the familiar, mafic dominated end members (e.g. the Deccan Traps, Siberia) through those containing appreciable volumes of felsic magmatism (Yellowstone, Parana-Etendeka) to the Gawler Range system in which magmatism is overwhelmingly felsic with rare, volumetrically minor $(\ll 10 \%)$ basalts and basaltic andesites. Significantly, it is clear that the mode of emplacement and possibly even magma transport and eruption mechanisms are controlled by their viscosity.

\section{Conclusions}

The calculated viscosities of the upper Gawler Range Volcanics range between 3.4-5.0 $\log \eta$ (Pa s): a range closer to those viscosities exhibited by basalts $(<3 \log \eta$ (Pas)) than that of typical felsic melts (Giordano et al., 2008). This viscosity range has been obtained by considering elevated temperatures $\left(\sim 950{ }^{\circ} \mathrm{C}\right.$ to $\left.1100^{\circ} \mathrm{C}\right)$, elevated halogen concentrations and low-moderate water content resulting in a depolymerised melt structure. The low viscosity magma erupted from a central cluster of feeder vents from which emanated large-scale lobate flows, representing a viable emplacement mechanism to produce a flood rhyolite province with volumetrically insignificant basalts and andesites. The volumes considered and high degree of homogeneity reported here and elsewhere in the literature (e.g. Allen et al., 2003) are suggestive of a well mixed magma system/chamber of batholitic proportions. The geodynamic implications of the production and expulsion of such extreme quantities of felsic magma in such a short time frame are non trivial. The volume and areal extent of such a flood rhyolite is directly analogous to that of preserved mafic LIPs, which are present throughout the geologic record, and are often attributed to upwelling of anomalously hot mantle in the form of mantle plumes. We view the fundamental driving force of the development of the GRV magmas to be a transient thermal anomaly analogous to such events. The evacuation of an anomalously hot and felsic (and therefore buoyant) magma chamber would be facilitated in this case by the low viscosities calculated, possibly at the expense of any cogenetic mafic magmas. We therefore present a viable mechanism for sustaining a large volume felsic igneous province, and suggest that the Gawler Range province represents an end- member of the Large Igneous Province clan.

Acknowledgements. This study was supported by an ARC Linkage Grant LP454301 to Hand, Schaefer and Betts. We acknowledge the contribution of PIRSA support in this project. Thank you to landowners in the Gawler Ranges for access and support. This is contribution 723 from the Australian Research Council National Key Centre for the Geochemical Evolution and Metallogeny of Continents (http://www.gemoc.mq.edu.au). Some analytical data were obtained using instrumentation funded by DEST Systemic Infrastructure Grants, ARC LIEF, NCRIS, industry partners and Macquarie University. Thank you to Kevin Grant and Graham Hutchinson for analytical support. We are grateful to J. Morgan and A. Castro for their helpful reviews, and to the reviewers of previous versions of this manuscript, all of whom improved the paper considerably.

Edited by: T. Gerya

\section{References}

Aiuppa, A., Federico, C., Paonita, A., Pecoraino, G., and Valenza, M.: S, Cl and $\mathrm{F}$ degassing as an indicator of volcanic dynamics: The 2001 eruption of Mount Etna, Geophys. Res. Lett., 29, 1559, doi:10.1029/2002g1015032, 2002.

Allen, S. R. and McPhie, J.: The Eucarro rhyolite, Gawler Range Volcanics, South Australia: A $>675 \mathrm{~km}^{3}$, compositionally zoned lava of Mesoproterozoic age, Geol. Soc. Am. Bull., 114, 1592-1609, 2002.

Allen, S. R., Simpson, C. J., McPhie, J., and Daly, S. J.: Stratigraphy, distribution and geochemistry of widespread felsic volcanic units in the Mesoproterozoic Gawler Range Volcanics, South Australia, Aust. J. Earth Sci., 50, 97-112, 2003.

Allen, S. R., McPhie, J., Ferris, G., and Simpson, C.: Evolution and architecture of a large felsic Igneous Province in western Laurentia: The $1.6 \mathrm{Ga}$ Gawler Range Volcanics, South Australia, J. Volcanol. Geoth. Res., 172, 132-147, doi:10.1016/J.Jvolgeores.2005.09.027, 2008.

Bagdassarov, N. S., Dingwell, D. B., and Webb, S. L.: Viscoelasticity of Crystal-Bearing and Bubble-Bearing rhyolite Melts, Phys. Earth Planet. In., 83, 83-99, 1994.

Betts, P. G., Giles, D., Foden, J., Schaefer, B. F., Mark, G., Pankhurst, M. J., Forbes, C. J., Williams, H. A., Chalmers, N. C., and Hills, Q.: Mesoproterozoic plume-modified orogenesis in eastern Precambrian Australia, Tectonics, 28, Tc3006, doi:10.1029/2008tc002325, 2009. 
Betts, P. G., Giles, D., Schaefer, B. F., and Mark, G.: 1600-1500 Ma hotspot track in eastern Australia: implications for Mesoproterozoic continental reconstructions, Terra Nova, 19, 496-501, doi:10.1111/J.1365-3121.2007.00778.X, 2007.

Blissett, A. H., Creaser, R. A., Daly, S. J., Flint, R. B., and Parker, A. J.: Gawler Range Volcanics, in: The geology of South Australia, Volume 1, The Precambrian, edited by: Drexel, J. F., Preiss, W. V., and Parker, A. J., Department of Mines and Energy, Adelaide, 106-124, 1993.

Bondre, N. R., Duraiswami, R. A., and Dole, G.: Morphology and emplacement of flows from the Deccan Volcanic Province, India, B. Volcanol, 66, 29-45, doi:10.1007/S00445-003-0294-X, 2004.

Bryan, S.: Silicic Large Igneous Provinces, Episodes, 30, 20-31, 2007.

Bryan, S. E., Riley, T. R., Jerram, D. A., Stephens, C. J., and Leat, P. T.: Silicic volcanism; an undervalued component of large igneous provinces and volcanic rifted margins, Special Paper, Geol. Soc. Am., 362, 97-118, 2002.

Bryan, S. E. and Ernst, R. E.: Revised definition of large igneous provinces (LIPs), Earth-Sci. Rev., 86, 175-202, doi:10.1016/J.Earscirev.2007.08.008, 2008.

Cashman, K., Pinkerton, H., and Stephenson, J.: Introduction to special section: Long lava flows, J. Geophys. Res.-Solid, 103, 27281-27289, 1998.

Christiansen, E. H., Bikun, J. V., Sheridan, M. F., and Burt, D. M.: Geochemical evolution of topaz rhyolites from the Thomas Range and Spor Mountain, Utah, Am. Mineral., 69, 223- 236, 1984.

Clemens, J. D., Holloway, J. R., and White, A. J. R.: Origin of an A-type granite; experimental constraints, Am. Mineral., 71, 317-324, 1986.

Coffin, M. F. and Eldholm, O.: Large Igneous Provinces - Crustal Structure, Dimensions, and External Consequences, Rev. Geophys., 32, 1-36, 1994.

Courtillot, V., Davaille, A., Besse, J., and Stock, J.: Three distinct types of hotspots in the Earth's mantle, Earth Planet. Sc. Lett., 205, 295-308, 2003.

Creaser, R. A. and White, A. J. R.: Yardea Dacite; large-volume, high-temperature felsic volcanism from the middle Proterozoic of South Australia, Geology, 19, 48-51, 1991.

Dingwell, D. B., Scarfe, C. M., and Cronin, D. J.: The effect of fluorine on viscosities in the system $\mathrm{Na}_{2} \mathrm{O}-\mathrm{Al}_{2} \mathrm{O}_{3} \mathrm{SiO}_{2}$; implications for phonolites, trachytes and rhyolites, Am. Mineral., 70, 80-87, 1985.

Dingwell, D. B., Brearley, M., and Virgo, D.: The dual role of ferric iron in liquid silicates: Effects on density and viscosity, Chem. Geol., 70, 86, 1988.

Dingwell, D. B. and Virgo, D.: Viscosities of melts in the $\mathrm{Na}_{2} \mathrm{O}-$ $\mathrm{FeO}-\mathrm{Fe}_{2} \mathrm{O}_{3}-\mathrm{SiO}_{2}$ system and factors controlling relative viscosities of fully polymerized silicate melts, Geochim. Cosmochim. Acta, 52, 395-403, 1988.

Dingwell, D. B., Knoche, R., and Webb, S. L.: The effect of F on the density of haplogranite melt, Am. Mineral., 78, 325-330, 1993.

Ewart, A., Milner, S. C., Armstrong, R. A., and Duncan, A. R.: Etendeka volcanism of the Goboboseb Mountains and Messum Igneous Complex, Namibia, Part I: Geochemical evidence of early cretaceous tristan plume melts and the role of crustal contamination in the Parana-Etendeka CFB, J. Petrol., 39, 191-225, 1998.
Fanning, C. M., Flint, R. B., Parker, A. J., Ludwig, K. R., and Blissett, A. H.: Refined Proterozoic evolution of the Gawler Craton, South Australia, through U-Pb zircon geochronology, Precambrian Res., 40-41, 363-386, 1988.

Gao, S., Luo, T. C., Zhang, B. R., Zhang, H. F., Han, Y. W., Zhao, Z. D., and Hu, Y. K.: Chemical composition of the continental crust as revealed by studies in East China, Geochim. Cosmochim. Acta, 62, 1959-1975, 1998.

Giles, C. W.: Petrogenesis of the Proterozoic Gawler Range Volcanics, South Australia, Precambrian Res., 40-41, 407-427, 1988.

Giordano, D. and Dingwell, D. B.: Non-Arrhenian multicomponent melt viscosity: a model, Earth Planet. Sc. Lett., 208, 337-349, doi:10.1016/S0012-821x(03)00042-6, 2003.

Giordano, D., Romano, C., Papale, P., and Dingwell, D. B.: The viscosity of trachytes, and comparison with basalts, phonolites, and rhyolites, Chem. Geol., 213, 49-61, doi:10.1016/J.Chemgeo.2004.08.032, 2004a.

Giordano, D., Romano, D. B., Dingwell, D. B., Poe, B., and Behrens, H.: The combined effects of water and fluorine on the viscosity of silicic magmas, Geochim. Cosmochim. Acta, 68, 5159-5168, doi:10.1016/J.Gca.2004.08.012, 2004b.

Giordano, D., Mangiacapra, A., Potuzak, M., Russell, J. K., Romano, C., Dingwell, D. B., and Di Muro, A.: An expanded nonArrhenian model for silicate melt viscosity: A treatment for metaluminous, peraluminous and peralkaline liquids, Chem. Geol., 229, 42-56, doi:10.1016/J.Chemgeo.2006.01.007, 2006.

Giordano, D., Russell, J. K., and Dingwell, D. B.: Viscosity of magmatic liquids: A model, Earth Planet. Sc. Lett., 271, 123-134, doi:10.1016/J.Eps1.2008.03.038, 2008.

Haapala, I., Frindt, S., and Kandara, J.: Cretaceous Gross Spitzkoppe and Klein Spitzkoppe stocks in Namibia: Topazbearing A-type granites related to continental rifting and mantle plume, Lithos, 97, 174-192, doi:10.1016/J.Lithos.2006.12.002, 2007.

Hildreth, W., Halliday, A. N., and Christiansen, R. L.: Isotopic and Chemical Evidence Concerning the Genesis and Contamination of Basaltic and Rhyolitic Magma Beneath the Yellowstone Plateau Volcanic Field, J. Petrol., 32, 63-138, 1991.

Holtz, F., Dingwell, D. B., and Behrens, H.: Effects of F, $\mathrm{B}_{2} \mathrm{O}_{3}$ and $\mathrm{P}_{2} \mathrm{O}_{5}$ on the Solubility of Water in Haplogranite Melts Compared to Natural Silicate Melts, Contrib. Mineral. Petr., 113, 492-501, 1993.

Jerram, D. A. and Widdowson, M.: The anatomy of Continental Flood Basalt Provinces: geological constraints on the processes and products of flood volcanism, Lithos, 79, 385-405, doi:10.1016/J.Lithos.2004.09.009, 2005.

Lejeune, A. M. and Richet, P.: Rheology of Crystal-Bearing Silicate Melts - an Experimental Study at High Viscosities, J. Geophys. Res.-Solid, 100, 4215-4229, 1995.

Lindsley, D. H.: Pyroxene thermometry, Am. Mineral., 68, 477493, 1983.

McPhie, J., DellaPasqua, F., Allen, S. R., and Lackie, M. A.: Extreme effusive eruptions: Palaeoflow data on an extensive felsic lava in the Mesoproterozoic Gawler Range Volcanics, J. Volcanol. Geoth. Res., 172, 148-161, doi:10.1016/J.Jvolgeores.2006.11.011, 2008.

Milner, S. C., Duncan, A. R., and Ewart, A.: Quartz Latite Rheoignimbrite Flows of the Etendeka Formation, North- 
Western Namibia, B. Volcanol., 54, 200-219, 1992.

Mysen, B. O. and Virgo, D.: Redox equilibria, structure, and properties of Fe-bearing aluminosilicate melts; relationships among temperature, composition, and oxygen fugacity in the system $\mathrm{Na}_{2} \mathrm{O}-\mathrm{Al}_{2} \mathrm{O}_{3}-\mathrm{SiO}_{2}-\mathrm{Fe}-\mathrm{O}$, Am. Mineral., 74, 58-76, 1989.

Mysen, B. R. O.: Interaction between water and melt in the system $\mathrm{CaAl}_{2} \mathrm{O}_{4}-\mathrm{SiO}_{2}-\mathrm{H}_{2} \mathrm{O}$, Chem. Geol., 88, 223-243, 1990.

Nekvasil, H.: Calculation of equilibrium crystallization paths of compositionally simple hydrous felsic melts, Am. Mineral., 73, 956-965, 1988.

Pankhurst, M. J., Schaefer, B. F., Betts, P. G.: Geodynamics of rapid voluminous felsic magmatism through time, Lithos, 123, 92-101, 2011.

Pinkerton, H. and Stevenson, R. J.: Methods of Determining the Rheological Properties of Magmas at Sub-Liquidus Temperatures, J. Volcanol. Geoth. Res., 53, 47-66, 1992.

Rajagopalan, S., Zhiqun, S., and Major, R.: Geophysical investigations of volcanic terrains: A case history from the Gawler Range Volcanic Province, South Australia, Explor. Geophys., 24, 769778, 1993.

Reese, C. C., Solomatov, V. S., and Moresi, L. N.: Heat transport efficiency for stagnant lid convection with dislocation viscosity: Application to Mars and Venus, J. Geophys. Res.-Planet., 103, 13643-13657, 1998.

Romano, C., Poe, B., Mincione, V., Hess, K. U., and Dingwell, D. B.: The viscosities of dry and hydrous $\mathrm{XAlSi}_{3} \mathrm{O}_{8}(\mathrm{X}=\mathrm{Li}, \mathrm{Na}$, K, Ca 0.5, Mg 0.5) melts, Chem. Geol., 174, 115-132, 2001.

Stewart, K. P.: High temperature felsic volcanism and the role of mantle magmas in Proterozoic Crustal growth, $\mathrm{PhD}$, Adelaide University, Adelaide, 1994.
Taylor, R. P. and Fallick, A. E.: The evolution of fluorine-rich felsic magmas: source dichotomy, magmatic convergence and the origins of topaz granite, Terra Nova, 9, 105-108, 1997.

Thouret, J. C.: Volcanic geomorphology - an overview, Earth-Sci. Rev., 47, 95-131, 1999.

Webster, J. D. and Rebbert, C. R.: Experimental investigation of $\mathrm{H}_{2} \mathrm{O}$ and $\mathrm{Cl}$-solubilities in F- enriched silicate liquids; implications for volatile saturation of topaz rhyolite magmas, Contrib. Mineral. Petr., 132, 198-207, 1998.

Webster, J. D. and De Vivo, B.: Experimental and modeled solubilities of chlorine in aluminosilicate melts, consequences of magma evolution, and implications for exsolution of hydrous chloride melt at Mt. Somma-Vesuvius, Am. Mineral., 87, 1046-1061, 2002.

White, R. S. and Mckenzie, D.: Mantle Plumes and Flood Basalts, J. Geophys. Res.-Solid, 100, 17543-17585, 1995.

Zaranek, S. E. and Parmentier, E. M.: The onset of convection in fluids with strongly temperature-dependent viscosity cooled from above with implications for planetary lithospheres, Earth Planet. Sc. Lett., 224, 371-386, doi:10.1016/J.Epsl.2004.05.013, 2004.

Zimova, M. and Webb, S.: The effect of chlorine on the viscosity of $\mathrm{Na}_{2} \mathrm{O}-\mathrm{Fe}_{2} \mathrm{O}_{3}-\mathrm{Al}_{2} \mathrm{O} 3-\mathrm{SiO}_{2}$ melts, Am. Mineral., 91, 344-352, 2006.

Zimova, M. and Webb, S. L.: The combined effects of chlorine and fluorine on the viscosity of aluminosilicate melts, Geochim. Cosmochim. Acta, 71, 1553-1562, doi:10.1016/J.Gca.2006.12.002, 2007. 